\title{
The Biopsychosocial Indicators of Health and Social Needs Related to Poverty and Adversity Among Vulnerable and Homeless Children in Tanzania: A Scoping Review
}

\author{
Winfrida Mwashala ( $\nabla$ wwmwashala@gmail.com ) \\ Flinders University \\ Julian Grant
}

Flinders University

Udoy Saikia

Flinders University

Diane Chamberlain

Flinders University

\section{Research Article}

Keywords: Adversities, indicators, vulnerable and homeless children, alienation, poverty, communities, primary health care

Posted Date: September 24th, 2021

DOl: https://doi.org/10.21203/rs.3.rs-805951/v1

License: @ (1) This work is licensed under a Creative Commons Attribution 4.0 International License. Read Full License 


\section{Abstract}

\section{Background}

Childhood poverty and adverse experiences contribute to child vulnerability, hindering healthy childhood growth and development pathways. Currently, the evidence on adversities related to vulnerable and homeless children's health and social needs in Tanzania is limited as a result of the complex social, economic, and political environment.

\section{Objectives}

This review investigates the biopsychosocial indicators of health and social needs related to vulnerable and homeless children facing poverty and a range of adversities in Tanzania. The main objective is to conduct a scoping review of the published literature to identify key evidence and to suggest future research needs.

\section{Methods}

A data search was undertaken between May and September 2020. Data sources included literature identified through electronic databases, such as CINAHL, Pub Med, Psych Info, and Medline. Further additional studies were located through a manual search of an organisational website and reference list. Studies were eligible for inclusion if they were: (i) Published in the English language; (ii) Peer-reviewed and published within the past 10 years; (iii) Subjects included children aged from 0-18 years who were vulnerable due to poverty and a range of adversities; and iv) Studies conducted only in Tanzania. The five-step scoping review process was followed, as developed by Arksey and Malley (2005). Data were analysed using thematic analysis, and conceptualised using the third iteration of Bronfenbrenner's bioecological theory to identify the indicators relating to vulnerable and homeless children's health and social needs $(1,2)$.

\section{Results}

Three themes were identified in the literature, including the increasing burden of disease and mortality, poor access to service delivery for vulnerable and homeless children, and a lack of adherence to local and national policies to protect children. The articles collated with similar themes were presented together. These themes were conceptualized using the third iteration of Bronfenbrenner's bioecological theory.

\section{Conclusion}

There is a need for greater investment in public health measures to detect vulnerable and homeless children's clinical risks, particularly given the COVID-19 pandemic which has exacerbated childhood adversities, with implications for children's overall health in Tanzania. Further research should explore ways to forge links for program implementation between multi-sector stakeholders and primary healthcare systems through early recognition of indicators and reduction of alienation within communities. This will enhance health and social support care for vulnerable and homeless children.

\section{Background}


Childhood poverty is increasing at an alarming rate globally, which interferes with the growth and development of children, including their psychosocial wellbeing $(3,4)$. The problem is greater in Sub-Saharan countries and Asia due to their long history of colonialism, the exploitation of raw materials, the introduction of credit currencies, and the imposition of policy reforms such as Structural Adjustment Policies (SAPs) through financial assistance from the International Monetary Fund (IMF). These SAPs have been designed to increase economic stability; however, they are blamed for reducing investment in health and wellbeing (4-6). As a result, there have been delays in establishing the infrastructure and services required by communities to access basic human needs such as health and social support services, education, a safe water supply, employment, and housing, compared to the situation in developed countries (7).

A child is defined as poor when both income-based and deprivation measures are below the poverty line (8). There are four approaches to defining poverty: the monetary approach, the capabilities approach, the social exclusion approach, and the participatory approach (9). The monetary and deprivation approaches will be used to define a child in poverty in this review. The monetary approach estimates the income of the child and the household assets, while deprivation measures refer to the child's capacity to access proper nutrition, clean water, public and primary healthcare services, safe and reliable shelter, and access to education $(10,11)$.

In Tanzania, childhood poverty is increasing. It is estimated that $74 \%$ of all Tanzanian children live in extreme poverty $(12,13)$. Although Tanzania has signed on to the Sustainable Development Goals (particularly, goal number one which aims to end poverty), children in this country are deprived of most of their fundamental rights due to living in a poverty-related environment (12). Collective risks associated with childhood poverty increase children's vulnerabilities, especially those who are already facing adversities due to other social circumstances $(12,13)$. Childhood adversities are defined as a wide range of adverse events that create significant risk to children's growth and development $(13,14)$.

There is an interplay between childhood poverty and adversities (15). The country's economic hardship perpetuates the likelihood of children facing social challenges that become significant childhood adversities $(7,16)$. Events such as climatic disasters, disease outbreaks, family breakdown, orphanhood, political conflicts, and ethnic challenges resulting in armed conflict increase the stressors on childhood growth and development pathways $(13,15)$. These types of events usually act as a catalyst in worsening the already constrained economy and increasing children's adversities in general (3). Childhood adversities have been widely discussed in studies conducted in developing countries, resulting in interference with biological and psychosocial growth; however, these indicators are not well known or understood in Tanzania (15).

There is increasing evidence that the COVID-19 pandemic has amplified children's poverty levels in poor households, increasing the overall burden by 15 percent, from 350 to 500 million children $(17,18)$. The COVID19 pandemic has exacerbated childhood adversity with serious implications and concerns for children's overall health in Tanzania.

\section{Aim}

This review investigates the biopsychosocial indicators of health and social needs related to vulnerable and homeless children facing poverty and a range of adversities in Tanzania. The main objective is to conduct a scoping review of the published literature to identify key evidence and to suggest future research needs. 


\section{Method}

A scoping review was undertaken as it enables the inclusion of all data from relevant studies to produce a synthesis of findings from a range of study designs. This process creates a broader understanding of the subject and the development of new concepts, following the five stages of the review (19). The review followed five main stages to investigate the biopsychosocial indicators of health and social needs related to poverty and adversity among vulnerable and homeless children. This included creating the research question; identifying the related articles; selecting the articles; charting, collating, and summarising; and reporting the findings (19). The review also followed the Preferred Reporting Items for Systematic Reviews and MetaAnalyses Extension for Scoping Reviews (PRISMA-ScR) checklist (20.

Identified search keywords were "Homeless AND children", or "vulnerable", "abandoned", "neglected", and "Tanzania", and "Health care access", and "socioeconomic factors", and "causes of death", and "adversity" and "risk assessment", and "neighbourhood".

A literature search of the following electronic databases was conducted from September 2019 to January 2021 (CINAHL, Pub Med, Psych Info, and Medline. In addition, there was a manual search of key journals and reference lists. A summary of the search strings used is illustrated in Table 1 from the Medline dataset. The inclusion and exclusion criteria for the articles were developed during this stage, as outlined in Table 2 below.

The search yielded 789 articles. A purposeful snowballing technique originating from the reference lists was used, which retrieved another 16 articles. A total of 805 articles were exported to Endnote 9, X9 Microsoft windows, and 69 duplicates were removed.

The articles were screened by title and abstract based on the established inclusion and exclusion criteria as outlined in Table 2, whereby 391 articles were excluded as they were irrelevant.

In the following stage, the first author read the full text of the 335 articles independently and later reviewed them again by the other authors. After this stage, 300 articles were removed for the following reasons: i) The studies were not conducted in Tanzania; ii) They discussed issues related to vulnerable and homeless children but did not identify social and health indicators, and iii) They were conducted in the vulnerable adult population. This resulted in a total of 35 articles for review, as outlined in (Figure 1).

\section{Quality Appraisal}

We used the Critical Appraisal Skills Program (CASP) tool for the quality appraisal of the selected articles. Although not common in scoping reviews, this enabled an evidence-based perspective. The overall quality of the reviewed studies was high in 30 articles, scoring eight out of ten on the CASP checklist. Methodological issues were related to the small sampling size, and not reporting the number of participants in the mixedmethods studies $(n=5)$. Charting was conducted on key items identified in the reviews, including author details, the number of participants included in the study, study design, indicators identified, individual health risks, and the societal impact, as per the study objectives.

\section{Results}


This review included a total of 35 articles from Tanzania which identified indicators related to the physical, psychological, and social needs of vulnerable and homeless children affected by poverty and a range of adversities. Studies were stipulated as follows: mixed methods $(n=15)$, qualitative studies $(n=15)$, and crosssectional studies $(n=5)$. We used the theoretical framework developed by Urie Bronfenbrenner to conceptualise the subject under scrutiny and to outline the indicators identified from the analysed themes (2).

Bronfenbrenner's bioecological theory is an evolutionary theoretical system for human development from childhood into adulthood $(2,20)$. The theory was first conceptualised in 1970 based on the idea of the family as a social institution and its influence on individual growth. The initial development phase of the theory occurred from 1973 to 1979, when it was identified as the ecological theory of human development, illustrating how the environment influences the growth and development of the child. The first and second phase of the theory was referred to as an ecological model due to its reference to the environment and nurturing $(2,20)$. The second phase occurred between 1980 and 1993 when significant theoretical growth occurred. In this second phase, the theory was reviewed, and evolved from an ecological worldview to an empirical science of humans as living organisms in a biological context in relation to their proximal environment; during this period, the theory developed into the bioecological theory (20). This occurred after a critical review of the key concepts in the original model, such as development and the ecological environment as they relate to micro- and macro-systems. The major limitations of the first and second phases of the ecological theory were the lack of a time factor in the model, and the association of biological factors to human development ecology, which was later addressed in the third phase of the bioecological theory (20).

The bioecological theory emphasises the process of adjustment between humans 'as living organisms', and how they relate to their environment and the intrinsic and extrinsic factors in their immediate surroundings. This review refers to the third phase of Bronfenbrenner's bioecological theory. We hypothesized that vulnerable and homeless children are the most immediate victims of poverty and adversity due to social circumstances that have affected their lives. The chronic history of poverty within Tanzania, and the fact that these children have been victims of abandonment and neglect after their parents' death due to diseases such as HIV/AIDS, influences the proximal effects of change in their lives (2).

The biological theory emphasises that the micro-, meso-, exo-, and macro-systems are nested in an interdependent way to shape individual growth and development. For these systems to be effective, proximal, and distal processes influence changes in human development. Therefore, it is evident that vulnerable and homeless children are alienated from bioecological structures and systems, compared to non-alienated children, as outlined in Figure 2 (2).

\section{Data analysis:}

The data were analysed using a thematic analysis methodology. Thematic analysis is a rigorous sequential process that uses six steps to identify and organise similar data into related patterns known as themes (21, 22). In the first step of this review, meticulous reading of the identified data was undertaken to familiarise the researcher with the key concepts related to vulnerable and homeless children's health and social indicators. In the second step, the data were interpreted to understand their meaning based on the research objectives and develop codes. This was followed by a research team discussion on establishing codes to enhance 
transparency and credibility. In the third stage, themes were developed from the codes established in stage two. Three themes were developed, which were led by the research question and the study objectives. Quality checks were conducted to identify if the analysed themes correlated with the research questions and objectives. All authors reached a consensus on the key thematic areas related to the findings.

Three themes were developed based on the identified indicators concerning vulnerable and homeless children's health and social needs. These included: (i) studies that explored the increasing burden of disease and mortality ( $n=19)$; (ii) studies that explored poor access to health and social support services $(n=9)$; and (iii) studies that explored lack of adherence to local and national policies aimed at protecting children $(n=6)$. These indicators illustrated how human development from early childhood is influenced by the immediate social environment, as illustrated by the bioecological theory (2).

At the micro-system level, the child is generally influenced by their immediate social and physical environment. This usually includes the proximal communities they live with (friends, parents, extended families, teachers, and carers), and the environment that nurtures the growth and development of the child. This also includes activities for learning social and educational skills such as early reading and play, and the characteristics of the peers with whom they engage. In this study, vulnerable and homeless children faced a range of adversities related to childhood poverty and decreased social capital (23). These factors have increased vulnerable and homeless children's risks to violence, maltreatment, stigma, addiction, and physical and sexual abuse, which have led to a vicious cycle of poverty. As a result, the research indicates that these children were at higher risk of disease and mortality compared to children in traditional households. Furthermore, chronic infectious conditions such as HIV/AIDS increase stress levels due to the accumulation of opportunistic infections and syndromes (15).

The meso- and exo-systems illustrate how the micro-systems are interconnected within entire communities and how they inform the macro-system. The macro-system includes cultural values, legal and political systems, and a given society's spiritual and socioeconomic context. The coordination at the macro- and meso-system levels were affected by structural challenges that affected the coordination of care (2). The findings indicated that the problem was exacerbated by the lack of adherence to local and national policies to protect children at the macro-system level. The available policies were not enforced or actively practiced because of a lack of awareness, a lack of collaboration, healthcare disparities, and bureaucratic inertia within the government health and social welfare systems. Therefore, children could not regularly access healthcare services.

\section{Key findings on the identified indicators of health and social needs}

These identified indicators emerged from the following themes, the burden of disease and increased mortality, poor accessibility to health and social support services, and the lack of adherence to local and national policies that aim to protect children. The indicators were grouped in relation to the systems within the bioecological theory and on indicators of health and social needs related to poverty and adversity among vulnerable and homeless children, as illustrated in Figure 3.

\section{Theme 1: Poor access to health and social support services}


Vulnerable and homeless children were identified as experiencing poor living conditions and facing hardship. They had experienced childhood adversities related to poor socioeconomic conditions, diseases that had resulted to their parents' deaths such as HIV/AIDS, and social displacement due to urbanisation and drought. Most of them were sleeping rough on the streets, begging for food, and living in an over-crowded environment. The following were revealed as indicators: i) disintegration and poor linkages with communities and resources (Joseph, 2013); ii) dropping out of school (24) iii) inadequate coordination of services to address vulnerable children's needs (25-28); and iv) patients' poor satisfaction(29) as outlined in Table 3.

\section{Theme 2: Lack of adherence to local and national policies aimed at protecting children}

Vulnerable and homeless children in Tanzania are at high risk of physical and psychosocial abuse. The incidence of rape, physical violence such as an attack, and unreasonable punishment such as being burned and raped, have been common among children. The social welfare and local government authorities are well informed about the child protection policies; however, the service providers and the community, in general, are not aware of the policies. There is a lack of evidence and national data on abuse cases and stigma in reporting rape cases for females. This results in intergenerational deprivation of children's rights, and this was identified in two themes stemming from the following social issues, (i) lack of a juvenile court (30)ii) poor law enforcement of available international laws(31-33)as outlined in Table 4.

\section{Theme 3: The burden of disease and increased mortality}

Vulnerable and homeless children were identified as being at risk of various medical conditions such as malaria, tuberculosis, and HIV/AIDS due to their lifestyle choices and adverse living environment (34-36). It was identified that these children died prematurely compared to housed children due to diseases that could have been prevented $(34,37)$. Their collective ill-health was associated with key indicators related to a range of physical and psychosocial factors, including: (i) addiction ((36, 38, 39)(ii) sexual abuse (40)(iii) maltreatment, abuse and violence (41-44) iv) stigma associated with substance use (45) v) neglect(26, 27, $46)$; vi) cognitive disabilities leading to orphanhood (47), vii) Trauma and assault (48); vii) parasitic and wound infection (49)viii) food insecurity (50); ix) Children social protection system not widely social known by health care workers (51); and $\mathrm{x}$ ) abuse and violence not reported (52), as outlined in Table 5.

\section{Discussion}

The bioecological theory illustrates how proximal factors and processes influence the human experience (2, 53). At the macro-system level, the socioeconomic status of the community can be influenced by the policies and legal systems that govern the country's economic systems (54). This has a significant impact on the growth and development of vulnerable and homeless children.

In Tanzania, the progress of the sustainable development goals, particularly goal number one which aims to end poverty, is slow-moving $(55,56)$. The country's economy has escalated from being a developing country to a middle-income country (57). The country has made progress in implementing poverty eradication policies which have assisted in establishing significant infrastructure, such as the construction of schools, health centres, and public transport, which are important for nurturing the growth and development of children (53). 
Nevertheless, poor reinforcement of existing child protection policies, and the poor linkages and coordination of the readily available community resources interferes with poverty eradication and child protection (28).

The reliance on assistance from, and partnerships with, international donors has held back the economy and increased public health susceptibility for those at higher risk, such as vulnerable and homeless children (5860). For instance, financial assistance from the International Monetary Fund (IMF), which has long been provided in exchange for policy reforms in developing countries, has resulted in delayed efforts rather than expected productive measures (4). These reforms have imposed Structural Adjustment Policies (SAPs), whereby the healthcare systems have been decentralised. Therefore, these changes have increased the bureaucratisation of the coordination of health and social services, which has contributed to further inequalities in the community $(4,61)$. This is due to unequal shared of resources where vulnerable children are most likely to not access public services such as health and education which increases further adversities in later adulthood.

The Sustainable Development Goals (SDGs) emphasise the enhancement of universal health coverage and improvements to population health (62). However, the findings of this review illustrate that vulnerable and homeless child are alienated from the systems outlined in the bioecological theory that emphasise inclusion, leading to poor access to health and social support services. The poor living environment of homeless children has predisposed them to a lack of access to health and social support services, which further predisposes them to health risks $(63,64)$. Therefore, these children face adverse risk factors due to the risks of poverty related to their social environment in which they are not provided with food, have a high risk of infectious diseases such as tuberculosis, and have high levels of psychological stress from living in overpopulated circumstances on the street (65). The associated SDG goals are less likely to be achieved because they are likely to be supported by structural adjustment policies, which tend to increase bureaucracy rather than decrease it, the opposite of what is expected by international financial aid partners(66).

The challenges of poor access to health and alienation significantly affect children's health across the region $(28,67)$. In addition, there is an increased concern for the country not reaching its intended health system improvements due to the COVID-19 pandemic. The pandemic has exacerbated living conditions, which were already constrained due to poor national infrastructure (57). Despite this, the pandemic has been contained within the country; however, the global crisis and the international travel ban have affected tourism, affecting government revenues and employment (57).

Tanzania is a signatory to the UN Convention on the Rights of the Child (UNCRC), which aims to promote, protect, and achieve children's rights, as expressed in the convention $(51,68)$. This review has identified a lack of adherence to local and international policies aimed at protecting children. This has fuelled maltreatment, as adults involved in abusing children have not been held accountable $(30,69)$.

As a result, there is an increasing prevalence of physical, emotional, and sexual abuse among children within Tanzania whereby vulnerable and homeless children suffer the most, as in most cases, they lack caregivers and are on their own (68). Furthermore, most of these children were identified as delinquents. They lacked juvenile prisons that could separate children and adults, which increases the likelihood of further adversities, such as maltreatment (30). 
The interplay between childhood poverty and adversities is associated with the burden of disease and increased mortality $(31,38)$. The indicators identified were relative to the risk factors for diseases such as HIV/AIDS, when children were sexually abused, or when they were sharing needles for drugs. They were at higher risk of malnutrition due to food insecurity and parasitic infections due to their poor living conditions and reliance on leftovers and cabbage $(38,65)$. The literature has identified that diseases such as HIV/AIDS, mental health issues, and malnutrition, when associated with other factors such as poverty and adversity, can have a long-lasting cumulative impact on children's physical and mental health $(70,71)$. These conditions interfere with neurological bio-markers and brain patterns and affect the developing child's intelligence quotient (IQ) and cognitive capacity $(15,31)$.

Bronfenbrenner's bioecological theory has been previously used as a tool for evaluation of policy interventions and implementation on sustainable development goals for poverty eradication $(20,72)$. This emphasizes the importance of an integrated approach at all system levels to enhance cohesion among communities to support healthy human growth and development. Although there have been efforts in Tanzania to support vulnerable and homeless children, there has been a lack of coordination in the measures that have been used, which has increased these children's lack of visibility in both the health and social support systems $(35,61)$. Therefore, vulnerable homeless children are at greater risk of contracting diseases, and transmitting them across the community (35). There is a need to identify measures that can promote health promotion activities to prevent the cycle of transmission of infection from the homeless community to the general population and vice versa $(35,40)$. A lack of awareness of tracking measures of these indicators in primary health care settings, and referral pathways opportunities, decreases healthcare professionals' opportunities to offer actionable and individualized care for vulnerable and homeless children $(40,73)$. These findings support the idea that campaigns to end poverty to meet the sustainable development goals are undertaken far too slowly.

For instance, in Zimbabwe, the government conducted a Poverty Assessment Study Survey (PASS) using Bronfenbrenner's bioecological model in a phenomenological observation of school-going children (74). The results indicated that the impact of poverty and disease, such as HIV/AIDS, reversed the previous progress made on the millennium development goals, which later became the sustainable development goals (74). This was due to an un-nested system as a result of poor bioecologically integrated frameworks due to political issues, poverty, and sanctions from international partners due to economic and political affiliations, all of which exacerbated the poor nurturing environment for children's growth and development $(20,74)$.

The emergence of COVID-19 has weakened the already constrained system in improving access to adequate healthcare (Kelly et al., 2020). As a result, there have been delays in the early identification of warning signs and the indicators of cumulative effects resulting from an acquired illness due to living in poverty and facing a range of adversities. There is a gap in how healthcare professionals engage with, track, and refer children who are at risk of vulnerability and homelessness (73). In addition, there is a lack of information on developing a coordinated approach within healthcare settings and with other stakeholders.

In Tanzania, this could be improved by enhancing measures to improve the social environment by enhancing community mobilization of readily available resources and increasing referral pathways and linkages within the community. Identification of early warning signs could add to the capacity of frontier workers, such as teachers and social workers, in the early recognition of signs and in establishing early referrals. 


\section{Limitations}

Many of the reviewed quantitative studies had only small sample sizes because most of these children are hard to reach due to their highly mobile lifestyle. Furthermore, the findings of this review may not be generalizable as they represent findings from only one country.

\section{Conclusion}

This review illustrates the influence of bioecological systems on the increasing physical and social health risks for vulnerable and homeless children living in poverty who are facing a range of adversities. We have demonstrated that the increase in the burden of disease and in mortality is related to the alienation of these children from the Tanzanian healthcare system. There is a need for greater investment in public health approaches to detect vulnerable and homeless children's clinical risks and identify referral pathways, particularly considering that the COVID-19 pandemic has exacerbated childhood adversities, negatively impacting children's overall health in Tanzania. Further research should explore ways to forge links for implementation between multi-sector stakeholders to reduce alienation and enhance health and social support care for vulnerable and homeless children.

\section{Abbreviations}

CINAHL Cumulative Index to Nursing and Allied Health Library

COVID Corona Virus Disease

SAPS Structural Adjustment Programs (SAPS)

IMF International Monetary Fund

PRISMA Preferred Reporting Items for Systematic Reviews and Meta-Analyse

CASP Critical Appraisal Skills Program

HIV/AIDS Human Immunodeficiency Virus/ Acquired Immunodeficiency Syndrome

SDG Sustainable Development Goals

UNCRC United Nation Convention on the Right of the Child.

IQ Intelligent quotient

\section{Declarations}

Ethics approval and consent to participate

Not applicable

Consent for publication

Page 10/25 
Not applicable

\section{Availability of data and material}

All data generated or analysed during this study are included in this published article

\section{Competing interests}

The authors declare no conflict of interest.

\section{Funding}

No funding was received for this paper.

\section{Authors' contributions}

WM: Conceptualise the idea for identifying the biopsychosocial indicators of health and social needs related to poverty and adversity among vulnerable and homeless children in Tanzania and developed the paper. JG: Provided supervision during the conceptual development process of the paper. US: Provided supervision during conceptual development of the paper and reviewed and provided feedback on all drafts. DC: Provided supervision and critiqued the conceptual development of the paper and provided feedback on all drafts. Provided approval for the work to proceed for publication. All authors provided final approval for submission.

\section{Acknowledgments}

The authors would like to acknowledge Shannon Brown and Leila Mohammad from the Flinders University, Library department for their help during the literature search process.

\section{References}

1. Braun V, Clarke VJQRiS, Exercise, Health. Reflecting on reflexive thematic analysis. 2019;11(4):589-97.

2. Bronfenbrenner U. Making human beings human: Bioecological perspectives on human development: Sage; 2005.

3. UNICEF D, editor Children on the Move. Workshop Report; 2016.

4. Forster T, Kentikelenis AE, Stubbs TH, King LPJSS, Medicine. Globalization and health equity: The impact of structural adjustment programs on developing countries. 2020;267:112496.

5. Ogar JN, Nwoye L, Bassey SAJIJoH, Innovation. Archetype of globalization: illusory comfort of neocolonialism in Africa. 2019;2(3):90 - 5.

6. Saikai U, Chalmers J, Dasvarma GJC, Wellbeing A, Schools VPi. MEASURING SUBJECTIVE WELLBEING. 2017.

7. Ferrone L, de Milliano MJCir. Multidimensional Child Poverty in three Countries in Sub-Saharan Africa. 2018;11(3):755 - 81.

8. McKinney SJIS. The relationship of child poverty to school education. 2014;17(3):203-16. 
9. Laderchi CR, Saith R, Stewart FJOds. Does it matter that we do not agree on the definition of poverty? A comparison of four approaches. 2003;31(3):243-74.

10. Ekbrand $\mathrm{H}$, Halleröd BJWD. The more gender equity, the less child poverty? A multilevel analysis of malnutrition and health deprivation in 49 low-and middle-income countries. 2018;108:221-30.

11. Cuaresma JC, Fengler W, Kharas H, Bekhtiar K, Brottrager M, Hofer MJPC. Will the Sustainable Development Goals be fulfilled? Assessing present and future global poverty. 2018;4(1):1-8.

12. Minujin A, Delamonica EJGCP, Well-Being. Multidimensional child poverty in Tanzania: analysis of situation, changes and sensitivity of thresholds1. 2012:263.

13. Lawson DW, Schaffnit SB, Hassan A, Ngadaya E, Ngowi B, Mfinanga SG, et al. Father absence but not fosterage predicts food insecurity, relative poverty, and poor child health in northern Tanzania. 2017;29(3):e22938.

14. Edward R, Art U. THE MENTAL HEALTH OF CHILDREN FACING COLLECTIVE ADVERSITY. 2012.

15. Nelson CA, Scott RD, Bhutta ZA, Harris NB, Danese A, Samara MJb. Adversity in childhood is linked to mental and physical health throughout life. 2020;371.

16. Lipina SJ, Evers KJFip. Neuroscience of childhood poverty: Evidence of impacts and mechanisms as vehicles of dialog with ethics. 2017;8:61.

17. Yoshikawa H, Wuermli AJ, Britto PR, Dreyer B, Leckman JF, Lye SJ, et al. Effects of the Global COVID-19 Pandemic on Early Childhood Development: Short-and Long-Term Risks and Mitigating Program and Policy Actions. 2020.

18. Kumar A, Nayar KR, Bhat LDJC, health am. Debate: COVID-19 and children in India. 2020;25(3):165-6.

19. Arksey H, O'Malley LJljosrm. Scoping studies: towards a methodological framework. 2005;8(1):19-32.

20. Rosa EM, Tudge JJJoFT, Review. Urie Bronfenbrenner's theory of human development: Its evolution from ecology to bioecology. 2013;5(4):243 - 58.

21. Braun V, Clarke V, Hayfield N, Terry GJHoRMiHSS. Thematic analysis. 2019:843 - 60.

22. Grant J, Lines L, Darbyshire P, Parry YJljons. How do nurse practitioners work in primary health care settings? A scoping review. 2017;75:51-7.

23. Heaton TB, Crookston B, Pierce H, Amoateng AYJljfeih. Social inequality and children's health in Africa: a cross sectional study. 2016;15(1):92.

24. Kacholi G. Assessment of factors influencing identification of the most vulnerable children in Tanzania: experiences from Morogoro rural district: Muhimbili University of Health and Allied Sciences; 2012.

25. Olsson J. From exclusion to inclusion: Young people's trajectories from home to street to reintegration in the Kagera region, Tanzania. 2017.

26. Henley R, McAlpine K, Mueller M, Vetter SJljomhs. Does school attendance reduce the risk of youth homelessness in Tanzania? 2010;4(1):1-8.

27. Mwashala W. The forgotten homeless children: Flinders University; 2018.

28. Mmasa J, Mbaula W. Social Protection: Targeting the Most Vulnerable Children The Case Study of Tanzania. 2016. 
29. Khamis K, Njau BJBhsr. Patients' level of satisfaction on quality of health care at Mwananyamala hospital in Dar es Salaam, Tanzania. 2014;14(1):1-8.

30. Chingonikaya EE, Salehe FSJAoCRI. Contribution of law enforcement institutions in protecting street children's rights in Dar Es Salaam, Tanzania. 2019:1-10.

31. Ng'ondi NB. Child protection in Tanzania: A dream or nightmare. Children and youth services review. 2015;55:10-7.

32. McAlpine K. Doing the right thing to protect children in Tanzania: An explanatory theory of the basic psychological process of doing the right thing and a practical theory to enable more and better protection of children: Fielding Graduate University; 2015.

33. Kijo-Bisimba H. Vulnerable within the Vulnerable: Protection of Orphaned Children Heading Households in Tanzania: University of Warwick; 2011.

34. Bowring AL, Luhmann N, Pont S, Debaulieu C, Derozier S, Asouab F, et al. An urgent need to scale-up injecting drug harm reduction services in Tanzania: prevalence of blood-borne viruses among drug users in Temeke District, Dar-es-Salaam, 2011. International Journal of Drug Policy. 2013;24(1):78-81.

35. Saleem HT, Mushi D, Hassan S, Bruce RD, Cooke A, Mbwambo J, et al. "Can't you initiate me here?": Challenges to timely initiation on antiretroviral therapy among methadone clients in Dar es Salaam, Tanzania. International Journal of Drug Policy. 2016;30:59-65.

36. Amury Z, Komba A. Coping strategies used by street children in the event of illness. 2010.

37. Unicef. Progress for Children beyond Averages: Learning from the MDGS. eSocialSciences; 2015.

38. Ndayongeje J, Msami A, Laurent YI, Mwankemwa S, Makumbuli M, Ngonyani AM, et al. Illicit drug users in the Tanzanian hinterland: population size estimation through key informant-driven hot spot mapping. AIDS and Behavior. 2018;22(1):4-9.

39. Francis GL, Waguespack SG, Bauer AJ, Angelos P, Benvenga S, Cerutti JM, et al. Management guidelines for children with thyroid nodules and differentiated thyroid cancer: the American Thyroid Association guidelines task force on pediatric thyroid cancer. 2015;25(7):716-59.

40. Dorsey S, Lucid L, Murray L, Bolton P, Itemba D, Manongi R, et al. A qualitative study of mental health problems among orphaned children and adolescents in Tanzania. 2015;203(11):864.

41. Ng'ondi NBJC, review ys. Child protection in Tanzania: A dream or nightmare. 2015;55:10 - 7.

42. Olsson J, Höjer S, Nyström L, Emmelin MJISW. Orphanhood and mistreatment drive children to leave home-a study from early AIDS-affected Kagera region, Tanzania. 2017;60(5):1218-32.

43. Lyimo J. The problem of street children in Tanzania: a case of Moshi municipality, Kilimanjaro region: Mzumbe University; 2013.

44. Luena F. Assessment of child abuse among street children: a case study of Dar es salaam city, Tanzania: Sokoine university of agriculture; 2011.

45. Zamudio-Haas S, Mahenge B, Saleem H, Mbwambo J, Lambdin BHJIJoDP. Generating trust: programmatic strategies to reach women who inject drugs with harm reduction services in Dar es Salaam, Tanzania. 2016;30:43-51.

46. Gaydosh LJD. Childhood risk of parental absence in Tanzania. 2015;52(4):1121-46. 
47. Escueta M, Whetten K, Ostermann J, O’Donnell KJBih, rights h. Adverse childhood experiences, psychosocial well-being and cognitive development among orphans and abandoned children in five low income countries. 2014;14(1):1-13.

48. Chalya PL, Hauli KA, Kayange NM, Mweteni W, Kapesa A, Ngallaba SEJTJoHR. Trauma admissions among street children at a tertiary care hospital in north-western Tanzania: a neglected public health problem. 2016;18(3).

49. Moremi N, Claus H, Hingi M, Vogel U, Mshana SEJDm, disease i. Multidrug-resistant Achromobacter animicus causing wound infection in a street child in Mwanza, Tanzania. 2017;88(1):58-61.

50. Fauk NK, Mwakinyali SE, Putra S, Mwanri LJIdop. Understanding the strategies employed to cope with increased numbers of AIDS-orphaned children in families in rural settings: a case of Mbeya Rural District, Tanzania. 2017;6(1):1-10.

51. Hassan DO. The situation of social welfare and child protection for vulnerable street-involved children in Tanzania: Where is the gap?: Høgskolen i Oslo og Akershus. Fakultet for samfunnsfag; 2013.

52. Gwanyemba J, Nyamase E, George BJIJoIR. Resilience of street children to violence, exploitation and abuse in Tanzanian cities: Evidence from Unga Limited Ward in Arusha City. 2016;2(7):60-5.

53. McLoughlin K, Rhatigan J, McGilloway S, Callinan J, Wright M, Kellehear A, et al. WA40 The good neighbour partnership: why do we need it? who is going to do it? how on earth are we going to evaluate it?: British Medical Journal Publishing Group; 2015.

54. Ashiabi GS, O’Neal KKJSO. Child social development in context: An examination of some propositions in Bronfenbrenner's bioecological theory. 2015;5(2):2158244015590840.

55. MacLachlan M, Mji G, Chataika T, Wazakili M, Dube AK, Mulumba M, et al. Facilitating disability inclusion in poverty reduction processes: group consensus perspectives from disability stakeholders in Uganda, Malawi, Ethiopia, and Sierra Leone. 2017.

56. Haug R, Hella JJFS. The art of balancing food security: securing availability and affordability of food in Tanzania. 2013;5(3):415-26.

57. Kelly TJC, Esselaar S, Saldarriaga Noel MA, Swinkels RA, Fatima F, Nabeta L, et al. Tanzania Economic Update: Addressing the Impact of COVID-19. The World Bank; 2020.

58. Ravallion MJNWP. On the Origins of the Idea of Ending Poverty. 2020(w27808).

59. Gertz G, Kharas H. Leave no country behind: ending poverty in the toughest places. 2018.

60. Ngoma C, Mayimbo SJAoM, Research HS. The negative impact of poverty on the health of women and children. 2017;7(6).

61. Olsson J, Höjer S, Emmelin MJGSW. From Exclusion to Inclusion-a Stepwise Process: a Qualitative Study of How the Reintegration Process Is Experienced by Young People Previously Living on Streets in the Kagera Region, Tanzania. 2018;5(4):211-24.

62. Fullman N, Barber RM, Abajobir AA, Abate KH, Abbafati C, Abbas KM, et al. Measuring progress and projecting attainment on the basis of past trends of the health-related Sustainable Development Goals in 188 countries: an analysis from the Global Burden of Disease Study 2016. 2017;390(10100):1423-59.

63. Nell E, Evans M, Gornick J. Child poverty in middle-income countries. LIS Working Paper Series; 2016. 
64. Muhsin HJ. Identification of Academic Challenges Facing Most Vulnerable Children in Zanzibar: A case study of West District: The Open University Of Tanzania; 2015.

65. Fauk NK, Mwakinyali SE, Putra S, Mwanri L. The socio-economic impacts of AIDS on families caring for AIDS-orphaned children in Mbeya rural district, Tanzania. International Journal of Human Rights in Healthcare. 2017.

66. Droti B, O’Neill KP, Mathai M, Dovlo DYT, Robertson JJBgh. Poor availability of essential medicines for women and children threatens progress towards Sustainable Development Goal 3 in Africa. 2019;4(Suppl 9):e001306.

67. Frumence G, Nyamhanga T, Mwangu M, Hurtig A-KJGph. Participation in health planning in a decentralised health system: experiences from facility governing committees in the Kongwa district of Tanzania. 2014;9(10):1125-38.

68. Tanzania U, Control CfD, Prevention PJNCfI, Control CfDC, Prevention MUoH, Sciences A. Muhimbili University of Health and Allied Sciences. Violence against children in tanzania: findings from a national survey, 2009. summary report on the prevalence of sexual, physical and emotional violence, context of sexual violence, and health and behavioural consequences of violence experienced in childhood. Dar es Salaam: UNICEF Tanzania, Division of Violence Prevention. 2011.

69. Olsson JJC, review ys. Violence against children who have left home, lived on the street and been domestic workers-A study of reintegrated children in Kagera Region, Tanzania. 2016;69:233-40.

70. Mutenyo F, Machingaidze S, Okello W, Otai M, Asekenye MJGSW. Multistage Processes of Identifying Children at Risk or Out of Family Care: a Case of DOVCU Project Methods in Uganda. 2019:1-13.

71. Murphy A, Palafox B, Walli-Attaei M, Powell-Jackson T, Rangarajan S, Alhabib KF, et al. The household economic burden of non-communicable diseases in 18 countries. BMJ glob. 2020;5(2):e002040.

72. Tomasetti DCJEoFS. Ecological Approach. 2016:1-6.

73. Mwashala W. 'The Forgotten Homeless Children'Health Worker Perceptions of the Needs of Children Living with HIV AIDS in Arusha, Tanzania: Flinders University, College of Nursing and Health Sciences.; 2018.

74. Chinyoka K, Naidu N. Uncaging the Caged: Exploring the Impact of Poverty on the Academic Performance of Form Three Learners in Zimbabwe. International Journal of Educational Sciences. 2013;5(3):271-81.

\section{Tables}

\section{Table 1 Summary of Medline search string}


1. Homeless youth/

2. Vulnerable population/

3. Child, Abandoned/

4. (Homeless children or vulnerable children or abandoned or neglected) $\mathrm{mp}(\mathrm{mp}=$ title, abstract, original title, name of substance word, subject heading word, keyword heading word, organism supplementary concept word, protocol supplementary concept word, rare diseases supplementary concept word, unique identifier synonyms)

5. 1 or 3 or 4

6. Tanzania

7. Africa Eastern/

8. 6 or 7

9. 5 and 8

10. Socioeconomic Factors/adversities

11. "Health Services Needs and Demand"/

12. (neighborhood and environment) $\mathrm{mp}(\mathrm{mp}=$ title, abstract, original title, name of substance word, subject heading word, keyword heading word, organism, supplementary concept word protocol supplementary concept word, rare disease supplementary concept word, unique identifier synonyms)

13. (((economic opportunities or health needs or neighborhood) and environment) or social needs) $\mathrm{mp}$ ( $\mathrm{mp}=$ title, abstract, original title, name of substance word, subject heading word, floating subheading word, keyword heading word, organism supplementary concept word, protocol supplementary concept word, rare diseases concept supplementary word, unique identifier synonym)

14. 10 or 11 or 12 or 13

15. 9 and 14

16. "Causes of death"/

17. "Risk assessment "/

18. (Causes of death and wellbeing) $\mathrm{mp}$ ( $\mathrm{mp}=$ =title, abstract, original title, name of substance word, subject heading word, keyword heading word, organism, supplementary concept word protocol supplementary concept word, rare disease supplementary concept word, unique identifier synonyms)

19. 16 or 17 or 18

20. 15 and 19

21. 5 and 9 and 15 and 19

22. 1 or 2 or 3 or 4 or 6 or 7 or 10 or 11 or 12 or 13 or 16 or 17 or 18

Table 2 Inclusion and exclusion criteria

Inclusion Criteria

They were published in the English language.

Peer-reviewed and published within the past ten years.

Included children aged from 0-18 years who were vulnerable due to poverty and adversities.

\section{Exclusion Criteria}

Reported in other languages

Papers published more than ten years ago.

Adult homeless and vulnerable population.

\section{Tanzania}

Other countries

Table 3: Indicators related to social needs 
Page $17 / 25$ 


\begin{tabular}{|c|c|c|c|c|c|c|}
\hline $\begin{array}{l}\text { Author } \\
\text { and years }\end{array}$ & $\mathrm{n}$ & $\begin{array}{l}\text { Participant } \\
\text { characteristics }\end{array}$ & $\begin{array}{l}\text { Study } \\
\text { design }\end{array}$ & Key indicator & $\begin{array}{l}\text { Health } \\
\text { risks }\end{array}$ & $\begin{array}{l}\text { Homeless } \\
\text { child } \\
\text { health } \\
\text { impact }\end{array}$ \\
\hline $\begin{array}{l}\text { Joseph } \\
2013\end{array}$ & 40 & (1-18 yrs) & Qualitative & $\begin{array}{l}\text { The care is } \\
\text { disintegrated with a } \\
\text { lack of linkages }\end{array}$ & $\begin{array}{l}\text { Social } \\
\text { exclusion }\end{array}$ & $\begin{array}{l}\text { Poor } \\
\text { access to } \\
\text { education } \\
\text { and } \\
\text { health, } \\
\text { and } \\
\text { disparities }\end{array}$ \\
\hline $\begin{array}{l}\text { Mmasa \& } \\
\text { Mbaula } \\
2016\end{array}$ & 200 & $\begin{array}{l}\text { (7-18 yrs) } \\
42.4 \% \text { girls, } \\
57.6 \% \text { boys }\end{array}$ & $\begin{array}{l}\text { Cross- } \\
\text { sectional }\end{array}$ & $\begin{array}{l}\text { Inadequate } \\
\text { coordination of } \\
\text { services to address } \\
\text { vulnerable children }\end{array}$ & $\begin{array}{l}\text { Poor } \\
\text { continuum } \\
\text { of care }\end{array}$ & $\begin{array}{l}\text { Poor } \\
\text { access to } \\
\text { education } \\
\text { and } \\
\text { health, } \\
\text { and } \\
\text { disparities }\end{array}$ \\
\hline $\begin{array}{l}\text { Olson et } \\
\text { al. } 2016\end{array}$ & 391 & $\begin{array}{l}\text { (10-24 yrs) } \\
18 \% \text { of girls, } \\
82 \% \text { of boys }\end{array}$ & $\begin{array}{l}\text { Mixed } \\
\text { methods }\end{array}$ & $\begin{array}{l}\text { Lack of community } \\
\text { cohesion }\end{array}$ & $\begin{array}{l}\text { Social } \\
\text { exclusion }\end{array}$ & $\begin{array}{l}\text { Poor } \\
\text { access to } \\
\text { education } \\
\text { and } \\
\text { health, } \\
\text { and } \\
\text { disparities }\end{array}$ \\
\hline $\begin{array}{l}\text { S Sayeed } \\
2010\end{array}$ & 12 & (12-15 yrs) & $\begin{array}{l}\text { Qualitative } \\
\text { study } \\
\text { (semi- } \\
\text { structured } \\
\text { interviews) }\end{array}$ & $\begin{array}{l}\text { Lack of community } \\
\text { cohesion }\end{array}$ & $\begin{array}{l}\text { Social } \\
\text { exclusion }\end{array}$ & $\begin{array}{l}\text { Poor } \\
\text { access to } \\
\text { education } \\
\text { and } \\
\text { health, } \\
\text { and } \\
\text { disparities }\end{array}$ \\
\hline $\begin{array}{l}\text { Henley et } \\
\text { al. } 2010 \\
(25)\end{array}$ & 1,098 & (13-18 yrs) & $\begin{array}{l}\text { Cross- } \\
\text { sectional } \\
\text { study }\end{array}$ & School drop-outs & $\begin{array}{l}\text { Poor } \\
\text { continuum } \\
\text { of care }\end{array}$ & $\begin{array}{l}\text { Poor } \\
\text { access to } \\
\text { education } \\
\text { and } \\
\text { health, } \\
\text { and } \\
\text { disparities }\end{array}$ \\
\hline $\begin{array}{l}\text { Priya G. } \\
\text { Nalkur } \\
2013\end{array}$ & 60 & (11-18 yrs) & $\begin{array}{l}\text { Qualitative } \\
\text { study }\end{array}$ & $\begin{array}{l}\text { Vulnerability due to } \\
\text { poor coordination } \\
\text { of care }\end{array}$ & $\begin{array}{l}\text { Poor } \\
\text { continuum } \\
\text { of care }\end{array}$ & $\begin{array}{l}\text { Poor } \\
\text { access to } \\
\text { education } \\
\text { and } \\
\text { health, } \\
\text { and } \\
\text { disparities }\end{array}$ \\
\hline $\begin{array}{l}\text { Mwashala } \\
2018\end{array}$ & 15 & $\begin{array}{l}\text { Health care } \\
\text { professionals }\end{array}$ & $\begin{array}{l}\text { Qualitative } \\
\text { study }\end{array}$ & $\begin{array}{l}\text { Inadequate } \\
\text { coordination of } \\
\text { services to address } \\
\text { vulnerable children }\end{array}$ & $\begin{array}{l}\text { Poor } \\
\text { continuum } \\
\text { of care }\end{array}$ & $\begin{array}{l}\text { Poor } \\
\text { access to } \\
\text { education } \\
\text { and } \\
\text { health, } \\
\text { and } \\
\text { disparities }\end{array}$ \\
\hline
\end{tabular}




\begin{tabular}{|c|c|c|c|c|c|c|}
\hline $\begin{array}{l}\text { Kacholi } \\
2012\end{array}$ & 81 & $\begin{array}{l}\text { Most } \\
\text { vulnerable } \\
\text { children } \\
\text { committees }\end{array}$ & $\begin{array}{l}\text { Qualitative } \\
\text { study }\end{array}$ & $\begin{array}{l}\text { Inadequate } \\
\text { coordination of } \\
\text { services to address } \\
\text { vulnerable children }\end{array}$ & $\begin{array}{l}\text { Poor } \\
\text { continuum } \\
\text { of care }\end{array}$ & $\begin{array}{l}\text { Poor } \\
\text { access to } \\
\text { education } \\
\text { and } \\
\text { health, } \\
\text { and } \\
\text { disparities }\end{array}$ \\
\hline $\begin{array}{l}\text { Khamis \& } \\
\text { Njau } 2014\end{array}$ & 422 & Families & $\begin{array}{l}\text { Mixed } \\
\text { methods }\end{array}$ & $\begin{array}{l}\text { Patient satisfaction } \\
\text { is poor }\end{array}$ & $\begin{array}{l}\text { Poor } \\
\text { continuum } \\
\text { of care }\end{array}$ & $\begin{array}{l}\text { Poor } \\
\text { access to } \\
\text { education } \\
\text { and } \\
\text { health } \\
\text { and } \\
\text { disparities }\end{array}$ \\
\hline
\end{tabular}

Table 4: Indicators for social protection

\begin{tabular}{|c|c|c|c|c|c|c|}
\hline $\begin{array}{l}\text { Author and } \\
\text { years }\end{array}$ & $\mathrm{n}$ & $\begin{array}{l}\text { Participant } \\
\text { characteristics }\end{array}$ & $\begin{array}{l}\text { Study } \\
\text { design }\end{array}$ & Key indicator & Health risks & $\begin{array}{l}\text { Homeles } \\
\text { child } \\
\text { health } \\
\text { impacts }\end{array}$ \\
\hline Ngondi, 2015 & 190 & (11-18 yrs) & Qualitative & $\begin{array}{l}\text { Poor law } \\
\text { enforcement }\end{array}$ & $\begin{array}{l}\text { Poor referrals } \\
\text { for abuse } \\
\text { and } \\
\text { maltreatment }\end{array}$ & $\begin{array}{l}\text { Child } \\
\text { abuse } \\
\text { and } \\
\text { neglect }\end{array}$ \\
\hline $\begin{array}{l}\text { Kijo-Bisimba, } \\
2011\end{array}$ & 300 & (10-18 yrs) & Qualitative & $\begin{array}{l}\text { Poor law } \\
\text { enforcement }\end{array}$ & $\begin{array}{l}\text { Poor referrals } \\
\text { for abuse } \\
\text { and } \\
\text { maltreatment }\end{array}$ & $\begin{array}{l}\text { Child } \\
\text { abuse } \\
\text { and } \\
\text { neglect }\end{array}$ \\
\hline $\begin{array}{l}\text { McAlpine, } \\
2015\end{array}$ & $\begin{array}{l}45 \\
\text { adults }\end{array}$ & $\begin{array}{l}\text { Caregivers of } \\
\text { vulnerable } \\
\text { children }\end{array}$ & Qualitative & $\begin{array}{l}\text { Poor law } \\
\text { enforcement }\end{array}$ & $\begin{array}{l}\text { Poor referrals } \\
\text { for abuse } \\
\text { and } \\
\text { maltreatment }\end{array}$ & $\begin{array}{l}\text { Child } \\
\text { abuse } \\
\text { and } \\
\text { neglect }\end{array}$ \\
\hline \multirow[t]{2}{*}{ Makuu, 2017} & \multirow[t]{2}{*}{60} & (10-17 yrs) & \multirow{2}{*}{$\begin{array}{l}\text { Mixed } \\
\text { methods }\end{array}$} & \multirow{2}{*}{$\begin{array}{l}\text { Poor law } \\
\text { enforcement }\end{array}$} & \multirow{2}{*}{$\begin{array}{l}\text { Poor referrals } \\
\text { for abuse } \\
\text { and } \\
\text { maltreatment }\end{array}$} & \multirow{2}{*}{$\begin{array}{l}\text { Child } \\
\text { abuse } \\
\text { and } \\
\text { neglect }\end{array}$} \\
\hline & & $\begin{array}{l}76 \% \text { male, } \\
24 \% \text { female }\end{array}$ & & & & \\
\hline $\begin{array}{l}\text { Cningonikaya } \\
\text { \& Salehe, } \\
2019\end{array}$ & 120 & (13-18yrs) & $\begin{array}{l}\text { Cross- } \\
\text { sectional }\end{array}$ & $\begin{array}{l}\text { Lack of a } \\
\text { juvenile } \\
\text { court }\end{array}$ & $\begin{array}{l}\text { Poor referrals } \\
\text { for abuse } \\
\text { and } \\
\text { maltreatment }\end{array}$ & $\begin{array}{l}\text { Child } \\
\text { abuse } \\
\text { and } \\
\text { neglect }\end{array}$ \\
\hline
\end{tabular}

Table 5: Indicators for the burden of disease and increased mortality 


\section{Author and N Participant Study Key indicator Individual health Societal years \\ characteristics design \\ risks \\ health \\ impact}

\begin{tabular}{|c|c|c|c|c|c|c|}
\hline $\begin{array}{l}\text { Amaury } \\
\text { Komba, } \\
2010\end{array}$ & 234 & (10-18 yrs) & $\begin{array}{l}\text { Mixed } \\
\text { methods }\end{array}$ & $\begin{array}{l}\text { Addiction to } \\
\text { substance } \\
\text { abuse }\end{array}$ & $\begin{array}{l}\text { Communicable } \\
\text { diseases } \\
\text { (sexually } \\
\text { transmitted and } \\
\text { blood-borne } \\
\text { infections) and } \\
\text { mental health }\end{array}$ & $\begin{array}{l}\text { The } \\
\text { burden of } \\
\text { disease } \\
\text { and } \\
\text { increased } \\
\text { mortality }\end{array}$ \\
\hline
\end{tabular}

\begin{tabular}{|c|c|c|c|c|c|c|}
\hline $\begin{array}{l}\text { Dorsey et } \\
\text { al., } 2015\end{array}$ & 34 & $\begin{array}{l}\text { Adolescents } \\
\text { (23 females; } 11 \\
\text { males) }\end{array}$ & Qualitative & Sexual abuse & $\begin{array}{l}\text { Communicable } \\
\text { diseases } \\
\text { (sexually } \\
\text { transmitted and } \\
\text { blood-borne } \\
\text { infections) and } \\
\text { mental health } \\
\text { issues }\end{array}$ & $\begin{array}{l}\text { The } \\
\text { burden of } \\
\text { disease } \\
\text { and } \\
\text { increased } \\
\text { mortality }\end{array}$ \\
\hline
\end{tabular}

$\begin{array}{llll}\begin{array}{l}\text { Ngondi, } \\ 2015\end{array} \quad 204 & (10-18 \mathrm{yrs}) & \begin{array}{l}\text { Mixed } \\ \text { methods }\end{array} & \begin{array}{l}\text { Maltreatment, } \\ \text { abuse, and } \\ \text { violence }\end{array}\end{array}$

\begin{tabular}{|c|c|c|c|c|c|c|}
\hline \multirow{2}{*}{$\begin{array}{l}\text { Saleem et } \\
\text { al., } 2016\end{array}$} & \multirow[t]{2}{*}{20} & 10 females & \multirow[t]{2}{*}{ Qualitative } & \multirow{2}{*}{$\begin{array}{l}\text { Stigma for } \\
\text { drug } \\
\text { addiction } \\
\text { users }\end{array}$} & \multirow{2}{*}{$\begin{array}{l}\text { Mental health } \\
\text { issues }\end{array}$} & \multirow{2}{*}{$\begin{array}{l}\text { The } \\
\text { burden of } \\
\text { disease } \\
\text { and } \\
\text { increased } \\
\text { mortality }\end{array}$} \\
\hline & & 10 males & & & & \\
\hline $\begin{array}{l}\text { McAlpine et } \\
\text { al., } 2010\end{array}$ & 1,923 & (15-24 yrs) & $\begin{array}{l}\text { Mixed } \\
\text { methods }\end{array}$ & $\begin{array}{l}\text { Abuse and } \\
\text { neglect }\end{array}$ & $\begin{array}{l}\text { Mental health } \\
\text { issues }\end{array}$ & $\begin{array}{l}\text { The } \\
\text { burden of } \\
\text { disease } \\
\text { and } \\
\text { increased } \\
\text { mortality }\end{array}$ \\
\hline $\begin{array}{l}\text { Nyambura, } \\
\text { Moremi, } \\
\text { Vogel \& } \\
\text { Mshana, } \\
2017\end{array}$ & 36 & & $\begin{array}{l}\text { Mixed } \\
\text { methods }\end{array}$ & $\begin{array}{l}\text { Parasitic } \\
\text { infection }\end{array}$ & $\begin{array}{l}\text { Communicable } \\
\text { diseases }\end{array}$ & $\begin{array}{l}\text { The } \\
\text { burden of } \\
\text { disease } \\
\text { and } \\
\text { increased } \\
\text { mortality }\end{array}$ \\
\hline $\begin{array}{l}\text { Hassan, } \\
2013\end{array}$ & 10 & (12-17 yrs) & Qualitative & $\begin{array}{l}\text { The } \\
\text { protection } \\
\text { system is not } \\
\text { widely known }\end{array}$ & $\begin{array}{l}\text { Abuse and } \\
\text { neglect }\end{array}$ & $\begin{array}{l}\text { The } \\
\text { burden of } \\
\text { disease } \\
\text { and } \\
\text { increased } \\
\text { mortality }\end{array}$ \\
\hline $\begin{array}{l}\text { Olsson, } \\
2017\end{array}$ & 251 & (13-24 yrs) & $\begin{array}{l}\text { Mixed } \\
\text { methods }\end{array}$ & $\begin{array}{l}\text { Orphanhood } \\
\text { and } \\
\text { maltreatment }\end{array}$ & $\begin{array}{l}\text { Mental health } \\
\text { issues }\end{array}$ & $\begin{array}{l}\text { The } \\
\text { burden of } \\
\text { disease } \\
\text { and }\end{array}$ \\
\hline
\end{tabular}


increased

mortality

\begin{tabular}{|c|c|c|c|c|c|c|}
\hline $\begin{array}{l}\text { Francis et } \\
\text { al., } 2015\end{array}$ & 1,954 & (15-24 yrs) & $\begin{array}{l}\text { Cross- } \\
\text { sectional }\end{array}$ & $\begin{array}{l}\text { Substance } \\
\text { abuse }\end{array}$ & $\begin{array}{l}\text { Mental health } \\
\text { issues }\end{array}$ & $\begin{array}{l}\text { The } \\
\text { burden of } \\
\text { disease } \\
\text { and } \\
\text { increased } \\
\text { mortality }\end{array}$ \\
\hline
\end{tabular}

\begin{tabular}{|c|c|c|c|c|c|c|}
\hline $\begin{array}{l}\text { Fauk et al., } \\
2017\end{array}$ & 10 & Adults/families & Qualitative & $\begin{array}{l}\text { Food } \\
\text { insecurity }\end{array}$ & $\begin{array}{l}\text { Nutritional } \\
\text { disorders }\end{array}$ & $\begin{array}{l}\text { The } \\
\text { burden of } \\
\text { disease } \\
\text { and } \\
\text { increased } \\
\text { mortality }\end{array}$ \\
\hline
\end{tabular}

\begin{tabular}{|c|c|c|c|c|c|c|}
\hline $\begin{array}{l}\text { Ndayongeje } \\
\text { et al., } 2018\end{array}$ & 436 & (18-54 yrs) & $\begin{array}{l}\text { Mixed } \\
\text { methods }\end{array}$ & $\begin{array}{l}\text { Addiction to } \\
\text { substance } \\
\text { abuse }\end{array}$ & $\begin{array}{l}\text { Communicable } \\
\text { diseases } \\
\text { (sexually } \\
\text { transmitted and } \\
\text { blood-borne } \\
\text { infections and } \\
\text { mental health } \\
\text { issues }\end{array}$ & $\begin{array}{l}\text { The } \\
\text { burden of } \\
\text { disease } \\
\text { and } \\
\text { increased } \\
\text { mortality }\end{array}$ \\
\hline
\end{tabular}

\begin{tabular}{|c|c|c|c|c|c|c|}
\hline Luena, 2011 & 100 & (8-17 yrs) & $\begin{array}{l}\text { Mixed } \\
\text { methods }\end{array}$ & $\begin{array}{l}\text { Maltreatment, } \\
\text { abuse, and } \\
\text { violence }\end{array}$ & $\begin{array}{l}\text { Mental health } \\
\text { issues }\end{array}$ & $\begin{array}{l}\text { The } \\
\text { burden of } \\
\text { disease } \\
\text { and } \\
\text { increased } \\
\text { mortality }\end{array}$ \\
\hline Lyimo, 2013 & 10 & (10-18 yrs) & Qualitative & $\begin{array}{l}\text { Maltreatment, } \\
\text { abuse, and } \\
\text { violence }\end{array}$ & $\begin{array}{l}\text { Mental health } \\
\text { issues }\end{array}$ & $\begin{array}{l}\text { The } \\
\text { burden of } \\
\text { disease } \\
\text { and } \\
\text { increased } \\
\text { mortality }\end{array}$ \\
\hline $\begin{array}{l}\text { Mccurdy et } \\
\text { al., } \\
2010\end{array}$ & 169 & $\begin{array}{l}\text { Adults } \\
\text { /families }\end{array}$ & $\begin{array}{l}\text { Mixed } \\
\text { methods }\end{array}$ & $\begin{array}{l}\text { Addiction to } \\
\text { substance } \\
\text { abuse }\end{array}$ & $\begin{array}{l}\text { Communicable } \\
\text { diseases } \\
\text { (sexually } \\
\text { transmitted and } \\
\text { blood-borne } \\
\text { infections) and } \\
\text { mental health } \\
\text { issues }\end{array}$ & $\begin{array}{l}\text { The } \\
\text { burden of } \\
\text { disease } \\
\text { and } \\
\text { increased } \\
\text { mortality }\end{array}$ \\
\hline $\begin{array}{l}\text { Bowring et } \\
\text { al., } 2013\end{array}$ & 267 & $87 \%$ males & $\begin{array}{l}\text { Mixed } \\
\text { methods }\end{array}$ & $\begin{array}{l}\text { Addiction to } \\
\text { substance } \\
\text { abuse }\end{array}$ & $\begin{array}{l}\text { Communicable } \\
\text { diseases } \\
\text { (sexually } \\
\text { transmitted and } \\
\text { blood-borne } \\
\text { infections) }\end{array}$ & $\begin{array}{l}\text { The } \\
\text { burden of } \\
\text { disease } \\
\text { and } \\
\text { increased } \\
\text { mortality }\end{array}$ \\
\hline $\begin{array}{l}\text { Gaydosh, } \\
2015\end{array}$ & 1,454 & & $\begin{array}{l}\text { Mixed } \\
\text { methods }\end{array}$ & $\begin{array}{l}\text { Abandonment } \\
\text { and neglect }\end{array}$ & $\begin{array}{l}\text { Delayed growth } \\
\text { milestones }\end{array}$ & $\begin{array}{l}\text { The } \\
\text { burden of } \\
\text { disease } \\
\text { and } \\
\text { increased } \\
\text { mortality }\end{array}$ \\
\hline
\end{tabular}




$\begin{array}{llll}\begin{array}{l}\text { Escueta, } \\ 2014\end{array} \quad 1,480 \quad(6-12 \text { yrs }) & \begin{array}{l}\text { Mixed } \\ \text { methods }\end{array} & \begin{array}{l}\text { Cognitive } \\ \text { disabilities for milestones } \\ \text { orphans and } \\ \text { the } \\ \text { abandoned }\end{array}\end{array}$

The burden of disease and increased mortality

\begin{tabular}{|c|c|c|}
\hline $\begin{array}{l}\text { Chalya et } \\
\text { al., } 2016\end{array}$ & 342 & (0-18 yrs) \\
\hline
\end{tabular}

\begin{tabular}{|c|c|c|c|c|c|c|}
\hline $\begin{array}{l}\text { Gwanyemba } \\
\text { \& Nyamase, } \\
2016\end{array}$ & 30 & (13-18 yrs) & Qualitative & $\begin{array}{l}\text { Abuse and } \\
\text { violence are } \\
\text { not reported }\end{array}$ & $\begin{array}{l}\text { Violence and } \\
\text { crime }\end{array}$ & $\begin{array}{l}\text { Increased } \\
\text { mortality }\end{array}$ \\
\hline $\begin{array}{l}\text { Mwashala, } \\
2018\end{array}$ & 15 & $\begin{array}{l}\text { Healthcare } \\
\text { professionals }\end{array}$ & Qualitative & $\begin{array}{l}\text { Abandonment } \\
\text { and neglect }\end{array}$ & $\begin{array}{l}\text { Mental health } \\
\text { issues }\end{array}$ & $\begin{array}{l}\text { Increased } \\
\text { mortality }\end{array}$ \\
\hline
\end{tabular}

\section{Figures}




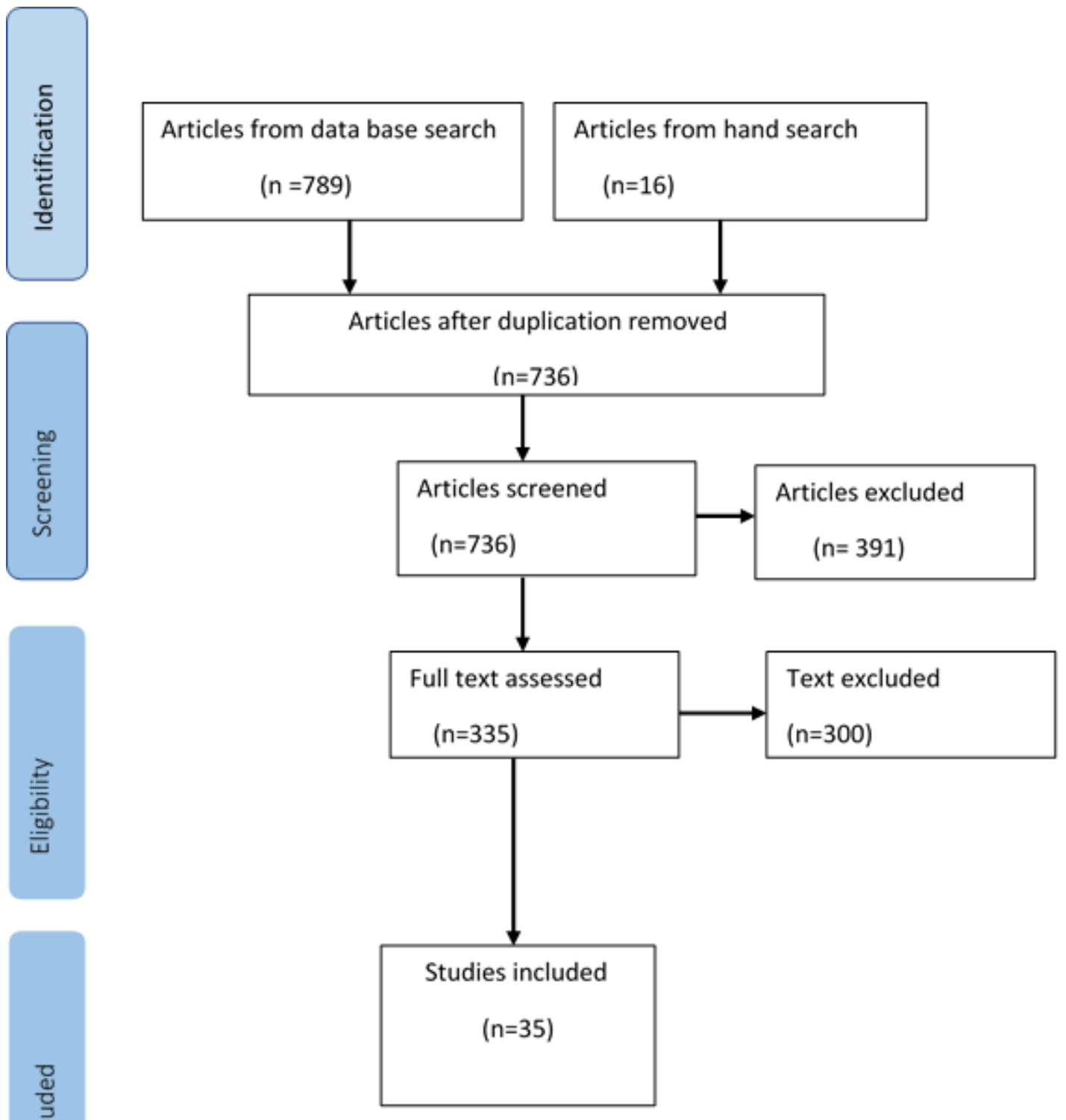

Figure 1

Prisma Flow 


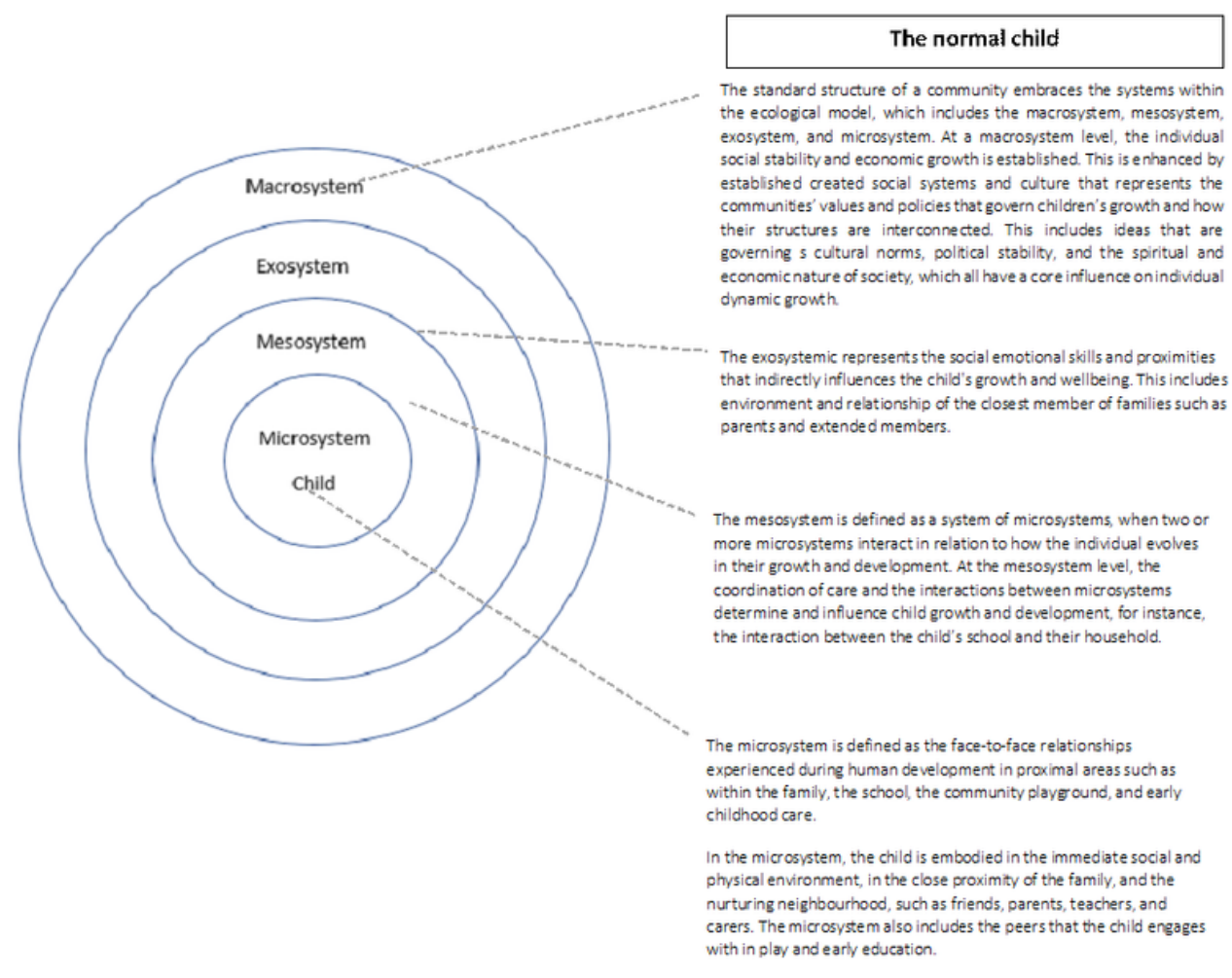

In Tanzania, despite the development progress underway to enhance the child hood deve looment, however the structural changes to support the economic growth to the entire population are weak and, in some cases, dysfunctional. This has led to socio economic inequalities, whereby the wunerable children inhabit in this population. They are at higher risks of poor health outcomes and social de gradation due to school dropping out and lack of social capital.

The de arth of kinship model of families has resulted to winerable children to be more at risks to maltreatment. Their rights are inffinged as most of these vulnerable children are orphans and homeless This is due to a lack of acherence to local and international policies, such as the Convention on the Rights of the Child (UNCRC), which were created with the aim of protecting children.

The social structure is not well developed to faclitate coordination and ne twork for activities related to winerable children. These further increases vulnerability for children facing adversity.

The proximal process determines individual development. Events such as vulnerability to chronic poverty and adversities lead to death among parents, leaving vulnerable children lacking the elements of the microsystem that act as key supports in child development due to lowered social capital.

\section{Figure 2}

\section{Alienation of vulnerable and homeless children as identified in the systems of the ecological framework}

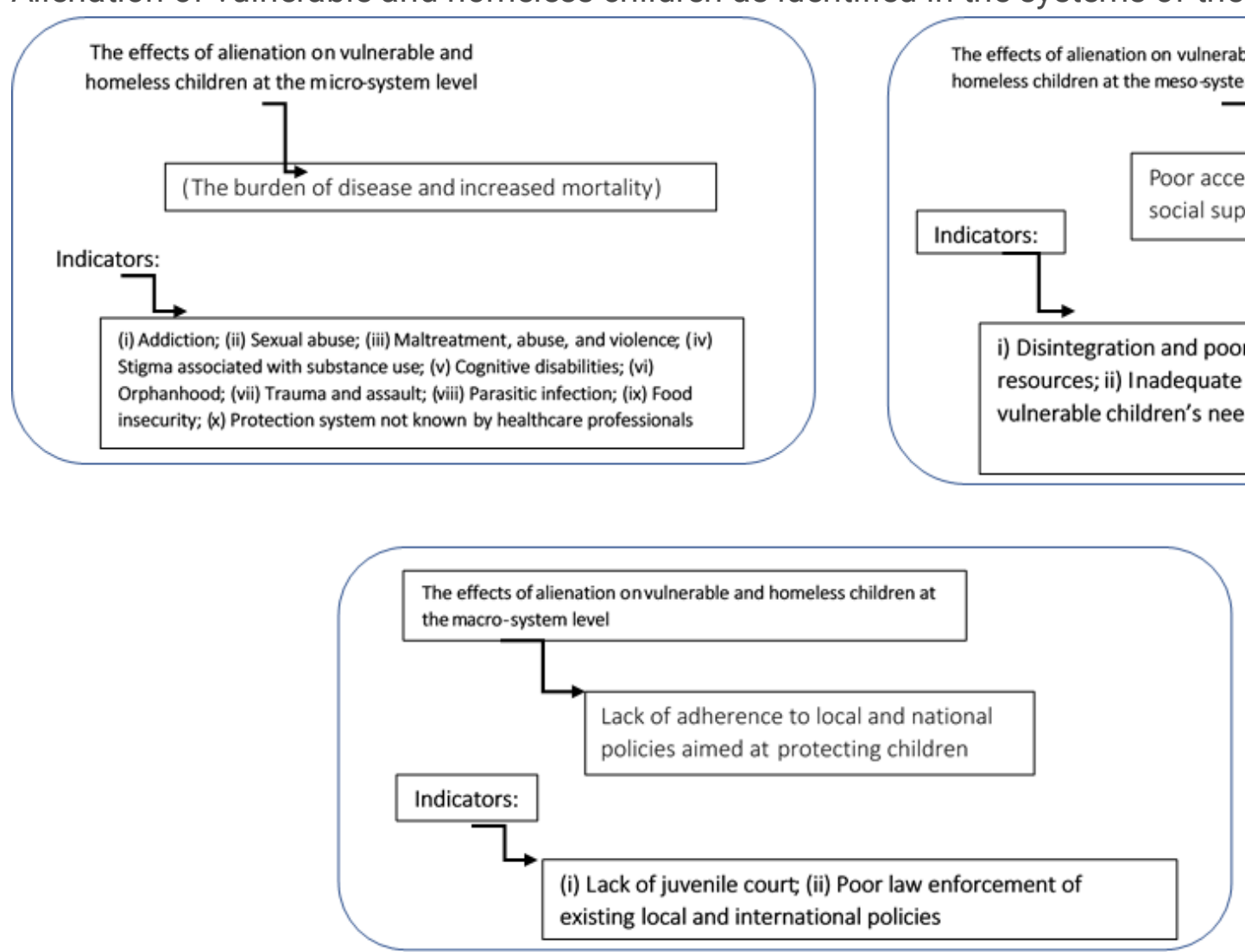

Figure 3 
Indicators of health and social needs related to poverty and adversity

Page 25/25 